\title{
Succession of Family Firms and Accounting Conservatism
}

\author{
Ying Chen \\ School of Management, Jinan University, Guangzhou, China \\ Email: jmcy7194@163.com
}

How to cite this paper: Chen, Y. (2019) Succession of Family Firms and Accounting Conservatism. Modern Economy, 10, 298-310.

https://doi.org/10.4236/me.2019.101020

Received: December 28, 2018

Accepted: January 20, 2019

Published: January 23, 2019

Copyright (C) 2019 by author(s) and Scientific Research Publishing Inc. This work is licensed under the Creative Commons Attribution International License (CC BY 4.0).

http://creativecommons.org/licenses/by/4.0/

\begin{abstract}
Using data of listed family firms and based on the multivariable regression model, this paper studies the changes in the quality of accounting information of family firms during the succession period as well as the regulating effect of successor' characteristic variables-educational level on the relation between succession and accounting conservatism. The results show: The succession of family firms will improve the level of accounting conservatism, suggesting that after the succession, the leader's personal authority and social capital declined, and the information disclosure level of the firm tends to be conservative; besides, the successors' personal qualities, particularly the educational and professional background will have a significant impact on the accounting conservatism after taking over the corporate. It can be seen that as a special stage, the succession will affect the accounting information disclosure policy of family firms, and it shows strong heterogeneity with the succession.
\end{abstract}

\section{Keywords}

Family Firms, Succession, Accounting Conservatism

\section{Introduction}

\subsection{Background of Research}

At present, large quantities of China's family firms are stepping into a peak period of intergenerational succession. Therefore, the succession of family firms is a key study direction in the field of family firm research. As the first generation of entrepreneurs of family businesses began to gradually withdraw from the operation of enterprises, what change will happen to the accounting conservatism when enterprises have to face the break of specific assets of former managers, the narrowing private information communication channels with external stake- 
holders? By comparing the changes in the accounting conservatism of family business before and after inheritance, we can gay a glimpse into some reasons for the quality characteristics of family business accounting information, and the prospects and expectations of the new governance structure and equity allocation of the family firms with the leadership of the second generation thus enriching the existing research on the factors influencing family business accounting conservatism and intergenerational succession.

Compared with the previous studies on the accounting conservatism of family firms, most of which focused on the factors in the quality of information under the framework of synergy effect and trench effect, we use the variable succession not only to enrich the theoretical framework of accounting conservatism, but also to expand the research content of succession of family firms. The research in this paper finds that compared with the founders of enterprises, the successors' individual authority and social capital decline obviously after intergenerational succession; therefore, they will be subject to more stringent internal and external supervision. When the family firms in China succeed, the heirs will improve the level of corporate accounting conservatism, and the personal management ability of the successor will play a positive role in this relationship.

\subsection{Significance of Research}

First of all, most of the current studies on the accounting conservatism are based on static analysis of various factors affecting information quality under the framework of synergy and entrenchment effect, but it is difficult to determine which factors play a leading role. The introduction of variable succession in this paper can clearly observe the influence of ownership transference and changes in the environment of the company, as well as impact that former entrepreneur's special assets will have on the family firm's succession, thus providing a new vertical and dynamic research sight.

From a practical point of view, at present, Chinese family firms have ushered in the peak period of the intergenerational succession. The next 10 to 20 years is key era for the entrepreneurs to pass on the controlling rights to the next generation. In fact, there are not many firms that can continue to be successful in business management, the situation of family firms' succession is not optimistic. How to successfully complete the intergenerational succession and realize the continuous operation of family business is an urgent problem to be solved. This paper discusses the changes in the quality of accounting information before and after the succession of family business power, and successors' response to the sharp decline in corporate value, which has important practical significance for predicting the governance direction and future development prospects of family enterprises under the leadership of new generation.

\section{Literature Review}

\subsection{Accounting Conservatism of Family Firms}

Firms that are managed or controlled by founding families, referred to as family 
firms, studies have shown that the quality of accounting information of these enterprises is lower than other companies, particularly, the family enterprises are implementing internally set accounting system., which feature low degree of timely loss confirmation [1] and lower quality of earnings information.

For the accounting conservatism of family firms, foreign literature have studied under the principal-agent theory earlier, comparing family companies with non-family companies to investigate the information disclosure of family firms [2]; In general, compared to non-family firms, family firms face less severe agency problems due to the separation of ownership and management, but more severe agency problems that arise between controlling and non-controlling shareholders. When large shareholders take control, they will have strong motivation to use their absolute power over the enterprise to encroach on the interests of the minority shareholders, thus diverting the interests of the major shareholders and the minority shareholders, resulting in the entrenchment effect. In the family firms, most of the controlling power is grasped in the hands of individuals or family members. Therefore, they tend to arbitrarily misappropriate the company's resources to satisfy their own interests, thus encroaching on the interests of small shareholders. In order to conceal their short-selling behavior, they will provide poor earnings quality [3], and lower degree of voluntary disclosure; the identity and power of the founding family also makes it easier to supervise and even interfere with the manager's behavior, as well as to obtain financial and accounting information from within, so the major shareholders have opportunity and motivation to hide losses leading to poor accounting conservatism; on the other hand, there is a large body of literature supporting the theory of "synergy effect", that is, when there is controlling shareholder, the large shareholders have the ability and motivation to supervise the managers and prevent the opportunistic behavior of the managers, thus avoiding the deviation of the interests of shareholders from management. In the family business, the family numbers own long-term holdings of the company's major equity, and the founding family is generally reluctant to obtain short-term interests through earnings management. Moreover, the founder of the company generally serve as CEOs, so the interests of shareholders and management tend to be consistent, and they can exercise strict supervision over other management or employees and hope to foster long-term employee loyalty; family owners are more willing to improve the efficiency of decision-making and corporate governance by changing the composition of board, such as increasing the number of non-family members and professional directors [4], so as to provide better earnings quality.

\subsection{Succession and Accounting Conservatism of Family Firms}

Based on the agency theory, the above-mentioned research analyzes the motives of the large shareholders to encroach on the interests of small shareholders under the "entrenchment effect". Existing research indicates that founders' personal social networks, such as political and business relationships foster accounting 
systems that provide lower quality of accounting information [5]. This relationship-based contract promotes and protects private interests. For example, through political rent-seeking, family firms can obtain internal news and resources in advance, so there is no need to improve quality of accounting information to obtain external resources [6].

However, this phenomenon can change significantly when succession happen in the family firms. Special assets such as private networks and political connections owned by the founders are difficult to be transferred between organizations and individuals [7]. For example, the social relationships with government [8], creditors, and business partners [9], while playing a key role in maintaining competitiveness and performance, are not replicable and transferable, suggesting the latent crisis in succession. Special assets that create value for the enterprise cannot be traded in the market like ordinary commodities, and it is difficult for successors to obtain external resources and information through informal channels, and providing low quality accounting information will be vulnerable to market penalties.

In response to the crisis of declining corporate value, the successors will improve decision-making efficiency and corporate governance by changing the composition and structure of the board, such as increasing the number of non-family members and increasing the number of directors with professional skills [10], providing better earnings quality, thereby gaining the trust of external shareholders and investors and reducing their debt costs, then the accounting system is constantly changing in the period of succession, and the accounting conservatism is constantly improving [11].

\section{Theoretical Analysis and Hypothesis}

\subsection{Succession and Accounting Conservatism}

The family firms in the early stage have a strong dependence on the leader's ideology, reputation or business relationship and other special assets. The "information profitability" naturally provides convenience for the "tunneling behavior" of the firms, and it also brings convenience for the firms to obtain resources, seek asylum and establish a stable political relationship. Therefore, the family companies are unwilling to obtain appropriate external resources by improving the quality of accounting information, nor are they penalized by the market for providing low-quality accounting information.

However, for the family firms that have gone through succession, this situation will be greatly reversed. From the perspective of special assets, the degree of asset specificity of the predecessor directly affects the changes of trust of the external stakeholders, which in turn affects the successor's choice of governance methods and accounting policies. The heirs who lost the special assets of their predecessor cannot use the convenience of the relational contract, commercial and political connections to obtain resources, and they will face the collapse of the trust mechanism between the stakeholders. If they provide low-quality ac- 
counting information, the firms may be penalized by the market. In order to reshape credibility, and make up for the organizational trust mechanism and reduce the friction cost of transactions, the successor will change the former accounting information policy, providing more conservative accounting information. Based on the above analysis, the following assumptions are made:

Hypothesis 1: Family firms after succession have higher accounting conservatism than family firms without succession.

\subsection{Regulating Effect of Successor's Academic Ability}

Relatively speaking, for the successors of higher education level, it is less prone to have short-sighted behaviors that whitewash financial statements and encroach on the interests of small shareholders, and they have weak motivation to overestimate profits for highlighting short-term business performance. On the one hand, highly educated heirs have more sensitive risk sensation and prefer conservative accounting method, but for heirs with low level of education, due to lack of knowledge about corporate governance and experience of management, they may seek more benefits for the company by adopting more radical and risky short-sighted behavior, and ignore the long-term development of the enterprise.

On the other hand, the succession of family business in China is in line with the rapid changes in politics, economy and market institution. In modern market transactions, formal contracts and rules are widely observed, successors who accept more modern education about enterprise management is more likely to adapt to the current situation. For example, the successors professional in economics and management contacts more knowledge of modern corporate governance and market rules, and is more motivated to guide the change of governance mechanism in the period of succession, the internal institutionalized management will be more integrated with the components of depersonalized factors, and the formal system will gradually replace the informal relational management of family businesses, improving the level of modern corporate governance, reducing level of family involvement and dependence of decision-making mechanism on personal authority [12], thereby strengthening supervision on management and financial reports, effectively improving quality of accounting information. Based on above analysis, the following assumptions are made:

Hypothesis 2: Successor's educational level plays a positive role in regulating relation between family firm' succession and the accounting conservatism.

\section{Research Design}

\subsection{Selection of Variables}

The main financial and governance data of this paper comes from the CSMAR database. Other data such as family firms' succession, the successor's education are collected manually through network and the website of Tianyancha. According to the definition of family firms, this paper selects the family firms in 
Shanghai or Shenzhen stock exchanges from 2011 to 2016 as basic sample. These observations include family businesses that have been succeed and those that have not been. This paper refers to the definition of family firms from Gu Qi [13], Xu Jingjing and Lu Changjiang [14], and defines firms that meet the following conditions as family firms: 1) The ultimate control rights are attributed to one person or a family; 2) The individual or family has substantial control over the firm; 3) The ultimate controller is directly or indirectly the largest shareholder of the firm.

In addition, this paper deals with the initial research sample according to the following principles: 1) Excluding financial listed companies, because the applicable accounting standards of this industry are different from other industries; 2) Excluding the newly listed companies in the current year, because the data of the previous year need to be calculated; 3) Excluding companies delisted and with negative shareholders' equity; 4) Excluding companies lacking financial data. This paper uses Stata12.0 for data processing to test the hypothesis. The main effect model is regressed using the OLS model, and the test of the regulating model applies to the method of interaction.

\subsubsection{Interpreted Variables: Accounting Conservatism}

Accounting conservatism is an important indicator to measure the quality of enterprise's accounting information. This paper adopts accounting conservatism as the interpreted variable, reflecting whether the family business has short-sighted tendency of earning manipulation under the successor's governance. With regard to the measurement of accounting conservatism, Basu [15] defines it by using asymmetric timeliness, that is, the asymmetric recognition of "good news" and "bad news" by accounting profit, asymmetric timeliness means that it is more timely to confirm bad news than to confirm good news, and accounting losses are more relevant with stock returns than profits; Givoly and Hayn [16] propose two measurements of accounting conservatism, one is the time of earnings sequence skewness (con_skewness), which believes that a sound accounting policy requires timely and complete confirmation of bad news, delays confirming good news, which leads to a negative bias in the earning distribution; the other is cumulative non-operating accruals divided by cumulative total assets (con_accrual). This paper mainly uses the company's annual indicator C-Score [17] to measure the degree of accounting conservatism of enterprises. The model for $\mathrm{C}$-Score measurement is as follows:

$$
\mathrm{EPS} / P=\beta_{0}+\beta_{1} \mathrm{DR}_{i t}+\beta_{2} \mathrm{RET}_{i t}+\beta_{3} \mathrm{DR}_{i t} * \mathrm{RET}_{i t}+\varepsilon
$$

EPS is for the company's earnings per share in year $t, P$ is the closing price of the company at the end of January of the $t$ year; RET is annual stock return rate considering cash dividend reinvestment for the company $i$ in year $t$, DR is a dummy variable, if RET $\leq 0$, then DR takes 1 ; otherwise it is $0 ; \beta_{2}$ expresses the response speed of good news; $\beta_{2}+\beta_{3}$ indicates the speed of response to bad news; $\beta_{3}$ indicates the difference in timeliness of conforming accounting 
earnings for bad news than good news (conservatism).

$$
\begin{aligned}
& \text { G-Score }=\beta_{2}=\mu_{0}+\mu_{1} \operatorname{size}+\mu_{2} \mathrm{mb}+\mu_{3} \text { lev } \\
& \text { C-Score }=\beta_{3}=\lambda_{0}+\lambda_{1} \operatorname{size}+\lambda_{2} \mathrm{mb}+\lambda_{3} \text { lev }
\end{aligned}
$$

Size means the size of the company; $\mathrm{mb}$ is the company's $\mathrm{P} / \mathrm{B}$ ratio; lev is the company's financial leverage.

Bring formula (2) and formula (3) into formula (1) to solve out $\mu_{i}$ and $\lambda_{i}$ and C-Score is obtained, which represents the accounting conservatism of each company for each fiscal year.

\subsubsection{Explanatory Variables}

For the first hypothesis of this paper, the explanatory variables are the succession of the family firms, this paper uses the dummy variable succession to measure it. When the successor enters the management and obtains the position of chief manager or chairman, the value is 1 , otherwise it is 0 .

\subsubsection{Managerial Capabilities of Successor}

This paper argues that the degree of education of the successor will affect the relationship between succession and changes in the accounting system. For example, the successor majoring in economics and management is exposed to more modern corporate governance and their knowledge of market rules will motivate them to guide the reforming direction of the governance mechanism in the succession period. This paper measures the academic ability of the successor from the two dimensions of diploma and majoring background. The diploma is used to measure the educational level. The dummy variable edu takes 0 when the successor is undergraduate, and 1 when the successor is graduate degree or above. Majoring background and professional titles obtained are used to measure professionalism, if the successor is majoring in management or obtains a senior management title, the variable major takes 1 , otherwise it is 0 .

The definition and explanation of each variable are shown in Table 1.

\subsection{Research Model}

\subsubsection{Succession and Accounting Conservatism}

In order to test the changes in the information quality of family enterprises after succession, this paper uses accounting conservatism as an indicator to study whether new leaders with weak relationship capabilities use more conservative accounting systems. In order to measure accounting conservatism, the company's annual indicator C-score need to be calculated, and then model 1 is used to verify the relationship between succession and accounting conservatism:

Model 1:

$$
\begin{aligned}
\text { score }= & \beta_{0}+\beta_{1} \text { succession }+\beta_{2} \text { growth }+\beta_{3} \text { roe }+\beta_{4} z+\beta_{5} \text { dev }+\beta_{6} \text { size } \\
& +\beta_{7} \text { tq }+\beta_{8} \sum \text { year }+\beta_{9} \sum \text { ind }+\varepsilon_{t}
\end{aligned}
$$

Score is a numerical variable, the larger the value is, the higher the degree of accounting conservatism is. Therefore, the coefficient $\beta_{1}$ is expected to be positive. 
Table 1. Variables and measurement.

\begin{tabular}{|c|c|}
\hline Variables & Measurement \\
\hline score & Conservatism through c-score model \\
\hline succession & It takes 1 if the successor is the chief manager or chairman, otherwise 0 \\
\hline ceo & It takes 1 if the chairman and the chiefl manager are held by one person, otherwise 0 \\
\hline major & $\begin{array}{l}\text { It takes } 1 \text { if the successor is majoring in management or obtains a senior management } \\
\text { title, otherwise } 0\end{array}$ \\
\hline edu & $\begin{array}{l}\text { It takes } 0 \text { when the successors is undergraduate, and } 1 \text { when the successor is graduate } \\
\text { degree or above. }\end{array}$ \\
\hline $\mathrm{bm}$ & Price per share/Net assets per share \\
\hline $\operatorname{dev}$ & The difference between control right and cash flow right \\
\hline growth & Growth rate of operating income \\
\hline lev & Asset-liability ratio \\
\hline roe & Rate of return on common stockholders' equity \\
\hline size & $\operatorname{Ln}($ asset $)$ \\
\hline tq & The value of to bin $\mathrm{q}$ \\
\hline year & Dummy variable of year \\
\hline indcd & Dummy variable of industry \\
\hline
\end{tabular}

\subsubsection{Regulating Effect of Successor's Academic Ability}

For hypothesis 2, in order to verify the role of successor's academic ability in regulating the relationship between succession and accounting conservatism, this paper takes $e d u$ and major as proxy variables to measure successor' diploma and professionalism, and considers whether the coefficient of the interaction term of succession and edu-sucedu is significant. The model is as follows,

Model 3.1:

$$
\begin{aligned}
\text { score }= & \beta_{0}+\beta_{1} \text { succession }+\beta_{2} \text { sucmajor }+\beta_{3} \text { size }+\beta_{4} \mathrm{dev}+\beta_{5} \text { roe } \\
& +\beta_{6} \text { ceo }+\beta_{7} \text { tq }+\beta_{8} z+\beta_{9} \text { year }+\beta_{10} \text { ind }+\varepsilon
\end{aligned}
$$

Model 3.2:

$$
\begin{aligned}
\text { score }= & \beta_{0}+\beta_{1} \text { succession }+\beta_{2} \text { sucedu }+\beta_{3} \text { size }+\beta_{4} \text { dev }+\beta_{5} \text { roe } \\
& +\beta_{6} \text { ceo }+\beta_{7} \text { tq }+\beta_{8} z+\beta_{9} \text { year }+\beta_{10} \text { ind }+\varepsilon
\end{aligned}
$$

Based on the former assumptions, we expect that the coefficient $\beta_{2}$ should be positive significantly, that is, the higher the successor' academic qualification is, the more motivated they are to guide the direction of the governance mechanism in the succession period, emphasizing the instrumental relationship that is more suitable for the rule of fairness, and paying attention to the long-term interests of the family firm and improving information quality.

\section{Empirical Results}

\subsection{Descriptive Statistics}

Due to the large number of samples and extreme values, in order to make the 
model results more accurate, this paper winsors by $5 \%$. As shown in the data in Table 2, the maximum value of accounting conservatism is 0.22 , the minimum value is -0.1 , and the median value is 0.04 . This indicates that the positive value is more than negative, and the accounting conservatism of listed family firms is generally higher. For the succession variable, the median value is 0 , the average value is 0.2 , and the proportion of enterprises with succession is low. According to statistics, there are a total of 121 family firms which have entered the period of succession, making for $26.5 \%$ of the total. The average value of the duality is 0.71 , which indicates that in the family business, the overall degree of centralization is higher.

In terms of control variables, the average asset-liability ratio (Lev) is 0.36 , the maximum is 0.89 , showing large financial risk; the minimum value of return on net assets is -1.81 , the maximum value is 0.45 , the median value is 0.07 , as the return on net assets is the profit indicator, the higher the return on net assets is, the higher the profit of the company and the increase in profits is, leading to lower possibility of manipulating earning within the enterprise, and the accounting conservatism will be higher. The average value of size is 21.76 , the minimum value is 19.65 , the maximum value is 25.71 , the standard deviation is 0.95 , and the median is 21.76 , indicating that the size of the listed family firms has certain volatility, so it is important to join size into the model as a control variable. In summary, most of the companies have not fully completed the process of succession, and the founders remain in the management of the company and play a administrative role.

\subsection{Succession and Accounting Conservatism}

By regression analysis of Model 1, the results are shown in Table 3. On the one hand, the F value is significant and the model passes the test. On the other hand,

Table 2. Descriptive statistics.

\begin{tabular}{ccccccc}
\hline variable & $\mathrm{N}$ & mean & sd & min & p50 & max \\
\hline score & 2150 & 0.04 & 0.03 & -0.10 & 0.04 & 0.22 \\
succession & 2150 & 0.20 & 0.40 & 0.00 & 0.00 & 1.00 \\
council & 2150 & 3.94 & 0.35 & 2.00 & 4.00 & 5.00 \\
supervision & 2150 & 3.24 & 0.75 & 1.00 & 3.00 & 10.00 \\
meeting & 2150 & 9.67 & 3.55 & 1.00 & 9.00 & 44.00 \\
ceo & 2150 & 0.71 & 0.28 & 0.00 & 1.00 & 1.00 \\
market & 2150 & 8.59 & 1.51 & 2.01 & 8.89 & 11.80 \\
edu & 2150 & 0.93 & 0.26 & 0.00 & 1.00 & 1.00 \\
roe & 2150 & 0.07 & 0.09 & -1.81 & 0.07 & 0.45 \\
lev & 2150 & 0.36 & 0.19 & 0.01 & 0.36 & 0.89 \\
size & 2150 & 21.76 & 0.95 & 19.65 & 21.62 & 25.71 \\
\hline
\end{tabular}


Table 3. Succession and accounting conservatism.

\begin{tabular}{|c|c|}
\hline variable & score \\
\hline \multirow[t]{2}{*}{ succession } & $0.003^{* * *}$ \\
\hline & $(2.60)$ \\
\hline \multirow[t]{2}{*}{ growth } & $0.007^{* * *}$ \\
\hline & $(6.97)$ \\
\hline \multirow[t]{2}{*}{ roe } & $-0.047^{\star * *}$ \\
\hline & $(-10.40)$ \\
\hline \multirow[t]{2}{*}{ dev } & $0.001^{\star}$ \\
\hline & (1.79) \\
\hline \multirow[t]{2}{*}{ tq } & $0.003^{* * *}$ \\
\hline & $(9.33)$ \\
\hline \multirow[t]{2}{*}{ ceo } & $-0.006^{* * *}$ \\
\hline & $(-4.35)$ \\
\hline \multirow[t]{2}{*}{ size } & $-0.29^{* * *}$ \\
\hline & $(-19.51)$ \\
\hline \multirow[t]{2}{*}{ cons } & $0.660^{* * *}$ \\
\hline & $(30.35)$ \\
\hline $\mathrm{N}$ & 2151 \\
\hline $\mathrm{R}^{2}$ & 0.47 \\
\hline F & 86.18 \\
\hline
\end{tabular}

the coefficient of succession is positively correlated with the accounting conservatism score at the level of $1 \%$, indicating that the succession of family companies has a positive correlation with accounting conservatism, that is, in the process of inheritance, since the special invisible special assets (such as political connections, reputation, etc.) is difficult to be passed on to the next generation, the sudden decline of the legitimacy of the leader's authority and the sharp rise of the supervisory power will prompt heirs to give up the original accounting systems within the family firms, and use more transparent accounting policies, and provide conservative corporate information, so that corporate stakeholders will not lose confidence in the company due to the period of transition.

\subsection{Regulating Effect of Successor's Academic Ability}

Columns (1) to (2) in Table 4 are the test results for Hypothesis2. From the results, we can see the intersection term sucmajor's regression coefficient is significant positive at $1 \%$ statistical level, indicating that the in-depth study of the professional knowledge is necessary for the successor to reform and focus on firm's long-term performance, avoiding short-sighted behavior; and columns (2) shows that the regression coefficient of intersection term sucedu is not significant. Since many entrepreneurs now choose to go to pursue a master's degree, 
Table 4. Regulating effect of successor' academic ability.

\begin{tabular}{|c|c|c|}
\hline \multirow{2}{*}{ Variable } & (1) & (2) \\
\hline & Score & Score \\
\hline \multirow[t]{2}{*}{ succession } & 0.002 & $0.003^{* *}$ \\
\hline & $(1.06)$ & $(2.09)$ \\
\hline \multirow[t]{2}{*}{ sucmajor } & $0.013^{\star * *}$ & \\
\hline & $(4.94)$ & \\
\hline \multirow[t]{2}{*}{ sucedu } & & 0.009 \\
\hline & & $(1.26)$ \\
\hline \multirow[t]{2}{*}{ dev } & -0.000 & -0.000 \\
\hline & $(-0.29)$ & $(-0.64)$ \\
\hline \multirow[t]{2}{*}{ roe } & $-0.029^{* * *}$ & $-0.040^{* * *}$ \\
\hline & $(-5.99)$ & $(-8.76)$ \\
\hline \multirow[t]{2}{*}{ ceo } & $-0.005^{\star * *}$ & $-0.005^{\star * *}$ \\
\hline & $(-3.40)$ & $(-3.59)$ \\
\hline \multirow[t]{2}{*}{$\mathrm{tq}$} & $0.002^{\star * *}$ & $0.003^{* * *}$ \\
\hline & $(7.46)$ & $(9.66)$ \\
\hline \multirow[t]{2}{*}{$z$} & $0.001^{* * *}$ & $0.001^{\star * *}$ \\
\hline & $(2.90)$ & $(2.84)$ \\
\hline \multirow[t]{2}{*}{ size } & $-0.029^{\star * *}$ & $-0.028^{\star * *}$ \\
\hline & $(-41.36)$ & $(-39.52)$ \\
\hline $\mathrm{N}$ & 2151 & 2151 \\
\hline $\mathrm{R}^{2}$ & 0.63 & 0.67 \\
\hline $\mathrm{F}$ & 201.87 & 212.35 \\
\hline
\end{tabular}

only to decorate their faculty, in fact, entrepreneurs' management skills are generally derived from past knowledge accumulation and management experience. The management thinking and mode have been largely fixed, and the diploma obtained after work is not enough to represent its knowledge and management ability.

\section{Conclusions and Prospects}

In this paper, the combination of theoretical analysis and empirical analysis is used to study the influence of family firms' succession on accounting conservatism, besides, personal traits - the academic ability of the successors can regulate the relationship of them. In terms of the empirical model of accounting conservatism, this paper uses the c-score model proposed by Khan and Watts [18]. The data selected in this paper came from the listed family enterprises from 2011 to 2016, and a total of 2150 observations were obtained. Then the paper uses the inheritance data, and uses the least squares method to regression with the ac- 
counting conservatism to start the regression analysis. The results of this paper are summarized as follows:

1) Compared with the founders' era, the successor with declining personal authority and social capital will be subject to more stringent internal and external supervision. When Chinese family enterprises are inherited, the heirs will improve the level of corporate accounting conservatism, which is not only the way in which the successor faces the unfavorable relationship network and the authoritative legitimacy of the supervision environment, so that the short-sighted behavior that is not conducive to the long-term development of the enterprise will be curbed.

2) From the inside of the family business, the personal characteristics of the successor, especially the education and professional background, have a significant impact on the accounting conservatism of the enterprise after the succession. The analysis found that the successor with higher professional ability and education level has received advanced management; they have keen sense of risk and a driving force for innovation, and tend to use sound accounting methods to improve corporate accounting conservatism

\section{Acknowledgements}

First and foremost, I would like to express my genuine appreciation and sincere gratitude to my respected supervisor Professor Shi. He has provided me with generous encouragement, patient instructions and insightful advice during my writing this thesis. Without his support and guidance, it would have been impossible for me to complete this thesis.

Secondly, I would also like to show my heartfelt thanks to those teachers who have taught me during my studies for their rigorous scholarship and thought-provoking lectures, which have benefited me a lot and I will cherish for the whole of my life.

Finally, I owe deep gratitude to my classmates and friends who have offered me constant support and great concern during my work on this thesis.

\section{Conflicts of Interest}

The author declares no conflicts of interest regarding the publication of this paper.

\section{References}

[1] Ball, R.., Kothari, S. and Robin, A. (2000) The Effect of International Institutional Factors on Properties of Accounting Earnings. Journal of Accounting and Economics, 29, 31-51. https://doi.org/10.1016/S0165-4101(00)00012-4

[2] Ali, A., Chen, T.Y. and Radhakrishnan, S. (2007) Corporate Disclosures by Family firms. Journal of Accounting \& Economics, 44, 238-286. https://doi.org/10.1016/j.jacceco.2007.01.006

[3] Fan, J. and Wong, T. (2002) Corporate Ownership Structure and the Informativeness of Accounting Earnings in East Asia. Journal of Accounting and Economics, 
33, 1-25. https://doi.org/10.1016/S0165-4101(02)00047-2

[4] Anderson, R. and Reeb, D.M. (2003) Founding Family Ownership and Firm Performance: Evidence from the S\&P 500. The Journal of Finance, 58, 1301-1328. https://doi.org/10.1111/1540-6261.00567

[5] Ball, R. and Shivakumar, L. (2005) Earnings Quality in U.K. Private Firms. Journal of Accounting and Economics, 39, 83-128. https://doi.org/10.1016/j.jacceco.2004.04.001

[6] Leuz, C., Nanda, D. and Wysocki, P. (2003) Earnings Management and Investor Protection: An International Comparison. Journal of Financial Economics, 69, 505-527. https://doi.org/10.1016/S0304-405X(03)00121-1

[7] Alchian, A. (1965) Some Economics of Property Rights. Politico, 30, 816-829.

[8] Faccio, M. (2006) Politically Connected Firms. American Economic Review, 96, 369-386. https://doi.org/10.1257/000282806776157704

[9] Hertzel, M.G., Li, Z., Officer, M.S. and Rodgers, K.J. (2008) Inter-Firm Linkages and the Wealth Effects of Financial Distress along the Supply Chain. Journal of Financial Economics, 87, 374-387. https://doi.org/10.1016/j.jfineco.2007.01.005

[10] Anderson, R. and Reeb, D.M. (2004) Board Composition: Balancing Family Influence in S\&P 500 Firms. Administrative Science Quarterly, 49, 209-237.

[11] Fan, J.P.H., Wong, T.J. and Zhang, T.Y. (2012) Founder Succession and Accounting Properties. Contemporary Accounting Research, 29, 283-311. https://doi.org/10.1111/j.1911-3846.2011.01099.x

[12] Chen, D.Q. and Zhong, Y.J. (2011) Institutional Efficiency, Family Approach and Family Investment Preference. Journal of Finance and Economics, 12, 107-117.

[13] Gu, Q., Deng, D.Q. and Lu, Q. (2006) Corporate Value of Separating Cash-Flow Rights From Control: Empirical Study on Family Owned Public Firms in China. Accounting Research, No. 4, 30-36.

[14] Xu, J.J. and Lv, C.J. (2011) The Nature of Executives in Family Firms and the Quality of Earnings: Evidence from Family Owned Public Firms in China. Management World, No. 3, 112-119.

[15] Basu, S. (1997) The Conservatism Principle and the Asymmetric Timeliness of Earnings. Journal of Accounting and Economics, 24, 3-37. https://doi.org/10.1016/S0165-4101(97)00014-1

[16] Bartov, E., Givoly, D. and Hayn, C. (2002) The Rewards to Meeting or Beating Earnings Expectations. Journal of Accounting and Economics, 33, 173-204. https://doi.org/10.1016/S0165-4101(02)00045-9

[17] Khan, (M. 2007) Are Accruals Mispriced? Evidence from Tests of an Intertemporal Capital Asset Pricing Model. Journal of Accounting and Economics, 45, 55-77.

[18] Khan, M. and Watts, R.L. (2009) Estimation and Empirical Properties of a Firm-Year Measure of Accounting Conservatism. Journal of Accounting and Economics, 48, 132-150. https://doi.org/10.1016/j.jacceco.2009.08.002 